\title{
導電ペーストの脱バインダー過程における金属粒子の触媒作用
}

\section{Catalytic Activity of Metal Particles in the Binder Burn- out of Conductor Paste}

\author{
杉村 健一，伊藤 弘展 \\ Ken-ichi Sugimura, Hironobu Ito
}

Received 7 April 2008; Accepted 16 May 2008

In order to investigate the behavior of binder burn-out for developing thin-film electrodes for the electronic devices, various metal pastes were employed and the effects on the binder burn-out were studied. It was found that the precious metal paste showed catalytic activity during the binder burn-out and that the catalytic activity depended on the manufacturing process. In case of the dispersion process with the destruction of the oxidation film, it was found that the catalyst activity was enhanced by the dispersion since the oxidation film was destroyed by the dispersion to form new catalyst active metal surfaces. On the other hand, in case of the dispersion process without the destruction of the oxidation film, the catalyst activity remained the same by the dispersion.

Keywords : Binder burn- out, Metal, Catalytic activity, Oxidation film

\section{1. 緒言}

電子機器の小型・高機能化の要求から, それに使用 される電子部品についても同様に小型・高性能化が求 められている。電子部品の小型・高性能化を達成する ためには様々な技術革新が行われているが，内部電極 として使用する各種金属ペーストの薄層・多積層化技 術もその一つである ${ }^{1.2)}$ 。電子部品は，一般にセラミ ックシート上に電極ペーストを印刷, 積層し, 電極と セラミックを同時焼成することで製造される。その積 層数が多層になればなる程，焼成時のクラック等 ${ }^{31}$ の 欠陷の問題が深刻となる。その主な原因は次の二つが 挙げられる。(1)セラミック層と電極層の収縮挙動の 差, (2)脱バインダー挙動の差である。前者の収縮挙動 差については，電極ペースト中にセラミック等を添加 し収縮を抑制する種々対策法が取組まれている ${ }^{4 \sim 6)}$ 。 著者らは，セラミック層よりも収縮が早い電極ペース 卜の収縮の制御には，ペースト中の粉体粒子の充填性 を上げ乾燥塗膜密度をいかに高くするかが重要な項目

\section{ノリ夕ケ機材株式会社 技術部}

（宁470-0293 愛知県西加茂郡三好町大字三好字東山320-3) TEL 0561-34-4906

Engineering Department, Noritake Kizai Co., Limited (320- 3 Higashiyama, Miyoshi, Miyoshi-cho, Nishikamo, Aichi 470-0293, Japan)
の一つであることを報告した。そして，そのためには 金属ペースト中に添加するより微小なセラミックの粒 径について，金属粒子間の 3 重結合点（スリースポッ

卜）にセラミック粒子が優先的に充填される場合が望 ましく，金属粒子径の 0.225 倍が最適充填における最 大粒子径であると報告した ${ }^{7}$ 。一方で，後者の脱バイ ンダー挙動については，今までに詳細の検討がなされ ていない。

本研究は，各種金属粒子を用いた電極ペーストの脱 バインダー挙動について検討し，ペースト中の樹脂の 燃焼時における金属粒子種による触媒作用の差を報告 する。さらに，触媒作用が金属表面の酸化皮膜の存在 の有無に影響があることに着眼し，ペースト製造にお ける微粒子の分散工程と金属表面の酸化皮膜の変化亡 触媒作用について報告する。

\section{2. 実験方法}

\section{1 金属ペーストの作製方法}

金属粉はFig. 1 に示すように，自社製の湿式合成 粉の $\mathrm{Pt}$ と $\mathrm{Pd}$ ，市販の $\mathrm{Ag}$ （三井金属鉱業（株）製 EHD), Ni (東邦チタニウム (株) 製 NF-40), Cu（三 井金属鉱業（株）製 1050Y）粉を選択し，エチルセル ロース (以下EC と省略。Dow Chemical Company 製 $\mathrm{EC} 10$ と 45）樹脂を夕ーピネオール（日本香料薬品 


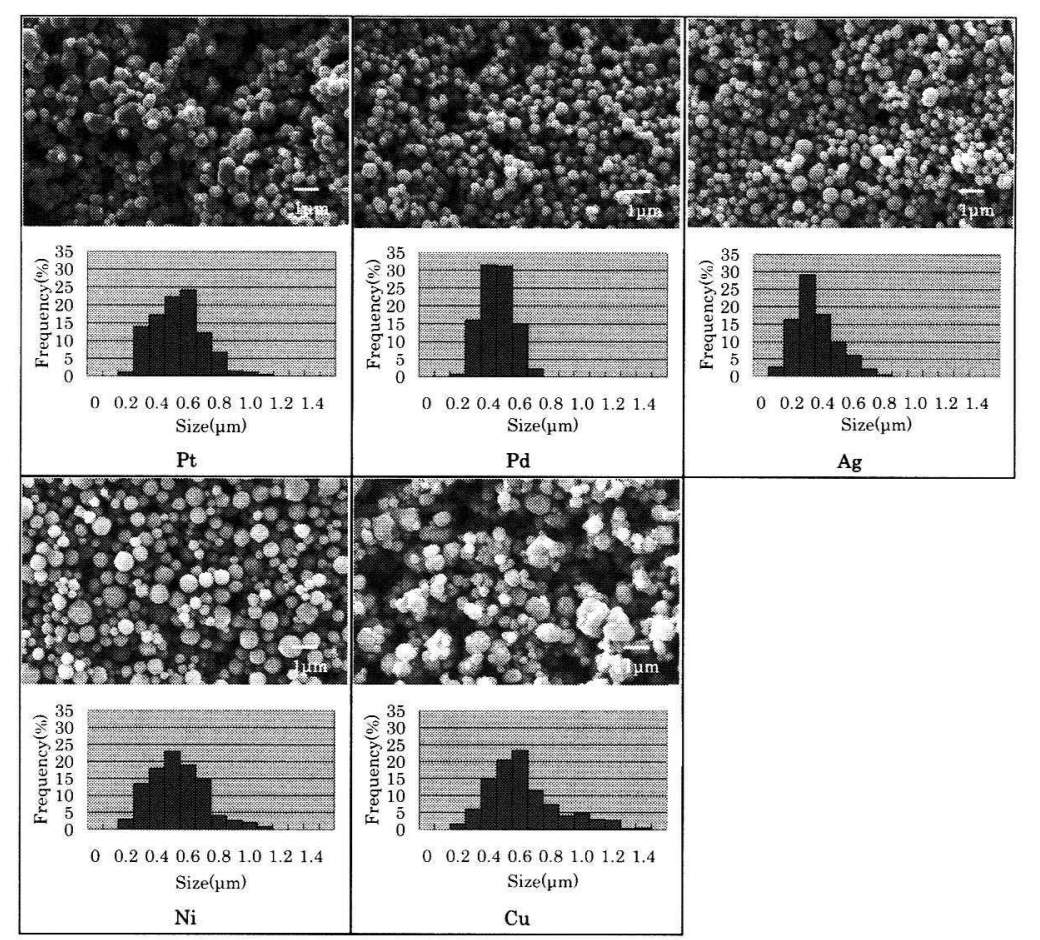

Fig. 1 SEM image and size distribution of various metal particles

（株）製ターピネオールC）に溶解させたビヒクルと金 属 3 本ロールミル（(株）井上製作所製 S-9X20）を使 用しペーストを作製した。

また，ペースト作製における分散方法は，3本ロー ルミルの他，材料への機械的損傷が少ない分散方法の 一つで超高圧の流体を対向衝突させることで分散させ る分散機（スギノマシン（株）製 HJP-25005）を使用 し，分散方法の差による脱バインダー挙動の変化を検 討した。

各々の評価に基づきペーストの作製方法は異なるた め，以下，各項に作製方法の詳細を述べる。

\section{2 金属ペーストの脱バインダー挙動の評価方法} 各種金属粉をビヒクルと混合し，3本ロールミルで 4 パス行いペーストを作製した（金属含有率 50wt％, EC 3wt \%，ターピネオール 47wt \%)。

作製したペーストの脱バインダー挙動を，TGDTA（(株）リガク製 TAS-300）を使用し， Al パン にて大気中で室温から $400{ }^{\circ} \mathrm{C}$ まで $10^{\circ} \mathrm{C} / \mathrm{min} て ゙$ 昇温 し測定した。

TG-DTA の解析方法としては，以下に着眼した。 $\mathrm{EC}$ 樹脂の燃焼の終点温度は，TG曲線で燃焼が完 了し，重量が一定を示すようになった温度を終点とし た。但し，酸化する金属のペーストについては，TG
曲線が $\mathrm{EC}$ 樹脂の燃焼による減量から金属の酸化によ る増量に転じるボトム温度を終点温度とした。EC 樹 脂の燃焼の変曲点温度は，TG の微分曲線のピーク温 度から求めた。 $\mathrm{EC}$ 樹脂の燃焼速度は, $\mathrm{TG}$ 減量曲線 の接線の傾きより, 単位温度あたりの重量減量変化率 で算出した。さらに，DTA ピークの面積からDTA ピーク発熱量を算出した。

また，金属粉単体の酸化挙動についても同様に TG-DTA を使用し， $\mathrm{Al}$ パンにて大気中で室温から $600{ }^{\circ} \mathrm{C}$ まで $10{ }^{\circ} \mathrm{C} / \mathrm{min} て ゙$ 昇温し測定した。

\section{3 分散パス回数の評価方法}

2. 2 と同様にペーストを作製した。その際，3本 ロールのパス回数を 1 〜 回まで変化させたペースト を作製し，それらの脱バインダー挙動を TG-DTAに て測定した。

$\mathrm{Ni}$ 粒子の分散後の箔化の確認には走査型電子顕微 鏡 SEM（日本電子（株）製 JSM-5600LV）を用い, 粒子の表面観察には透過型電子顕微鏡 TEM（(株）日 立製作所製 $\mathrm{H}-9000$ ）を用いた。

各種金属粉の結晶相の同定にはX線回折装置 XRD （(株）リガク製 RAD-RVB）を使用し，金属粉中の酸 素の定量には不活性ガス融解-赤外線吸収法 (LECO ジャパン（株）製 TC-436AR）にて測定した。 
Table 1 Decomposition behavior of various metal pastes

\begin{tabular}{c|c|c|c|c}
\hline $\begin{array}{c}\text { Type of } \\
\text { metals }\end{array}$ & $\begin{array}{c}\text { TG decomposition } \\
\text { temperature }\left({ }^{\circ} \mathrm{C}\right)\end{array}$ & $\begin{array}{c}\text { TG inflection } \\
\text { point temperature }\left({ }^{\circ} \mathrm{C}\right)\end{array}$ & $\begin{array}{c}\text { Decomposition } \\
\text { speed }\left(\% /{ }^{\circ} \mathrm{C}\right)\end{array}$ & $\begin{array}{c}\text { Number of } \\
\text { DTA peaks }\end{array}$ \\
\hline$\ldots \%$ & 350 & 255 & 0.079 & 2 \\
$\mathrm{Pt}$ & 237 & 174 & $0.14,0.066$ & 2 \\
$\mathrm{Pd}$ & 192 & 184 & 0.38 & 1 \\
$\mathrm{Ag}$ & 265 & 242 & 0.12 & 1 \\
$\mathrm{Ni}$ & 340 & 228 & 0.028 & 2 \\
$\mathrm{Cu}$ & 270 & 235 & 0.041 & 1 \\
\hline
\end{tabular}

※ Vehicle only (Metal less)
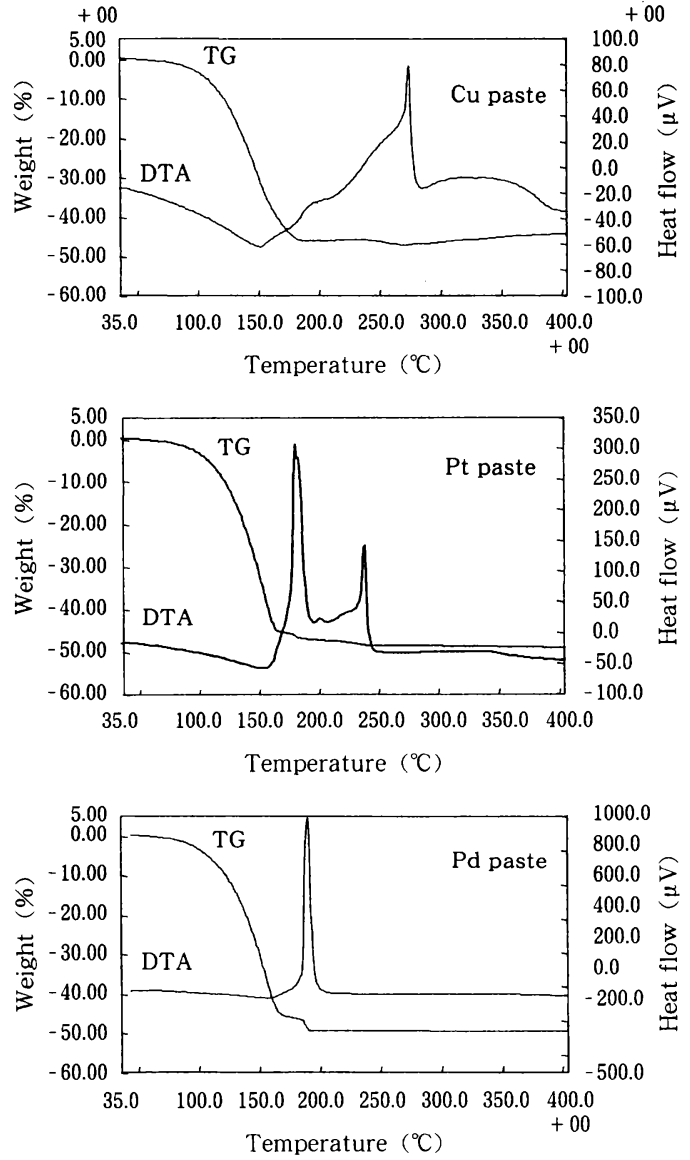

Fig. 2 TG-DTA charts of various pastes

\section{4 分散方法の評価方法}

分散の進行に伴う脱バインダー挙動の変化が顕著で あった Niについては，3本ロールミルに対し，金属 粒子に機械的損傷を与えない分散方法として，対向衝 突分散機を選択し，同一組成で分散したペーストの脱 バインダー挙動を同様にTG-DTAにて測定した。ま た，粒子の表面観察をTMA にて行った。

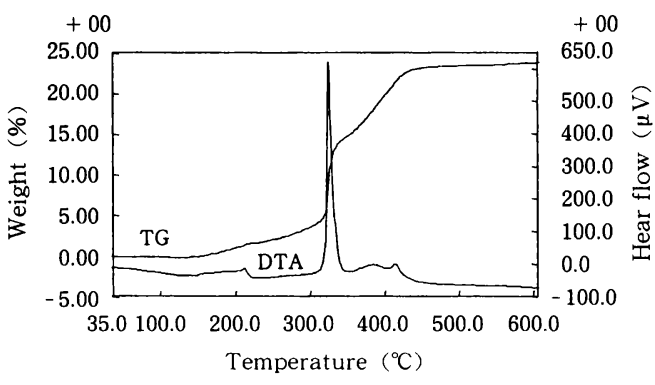

Fig. 3 TG-DTA chart of $\mathrm{Cu}$ powder

\section{3. 結果と考察}

\section{1 金属ペーストの脱バインダー挙動}

Table 1 には，各種金属ペーストの脱バインダー挙 動について，Fig. 2 に例として示した TG-DTA 測定 から算出した結果を，ペースト作製の際に使用したビ ヒクル単体の測定結果も対照として入れて示す。

ビヒクル単体に対し，金属ペーストの場合，いずれ の場合も燃焼温度の低温化が確認された。金属種によ り，その挙動は著しく異なった。 $\mathrm{Pt}, \mathrm{Pd}, \mathrm{Ag}$ といっ た貴金属ペーストは著しい燃焼温度の低下が確認さ れ，特に Pt，Pd で顕著であった。一般に，これら貴 金属については様々な触媒作用を持つことが知られて いるが，EC 樹脂の燃焼に関しても触媒作用があり燃 焼温度を低下させると考えられる。

さらに, $\mathrm{Ni}, \mathrm{Cu}$ ペーストでも燃焼温度の低下が見 られ，卑金属でも触媒作用により， EC 樹脂の燃焼温 度を若干低温化させると考えられる。但し，Fig. 3 に 示した $\mathrm{Cu}$ 粉の TG-DTA 測定から分かるように, $\mathrm{Cu}$ は約 $140{ }^{\circ} \mathrm{C}$ といった著しく低温から酸化するため,

Fig. 2 の $\mathrm{Cu}$ ペーストの測定では， EC 樹脂の燃焼に よる減量と並行して $\mathrm{Cu}$ 粉の酸化による増量が起こる ことから，TG曲線が減少と増加を繰り返すため，大 気中の測定では $\mathrm{EC}$ 樹脂の燃焼の終点温度は明確に確 


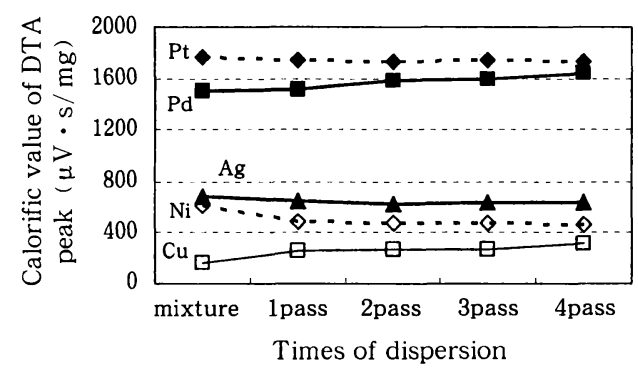

Fig. 4 Relationship between times of dispersion and calorific value of DTA peak

\section{認できなかった。}

燃焼速度については，EC 樹脂の燃焼温度の低温化 が見られた貴金属ペーストは著しく早く, 触媒作用に より EC 樹脂の燃焼がより低温から急激に起こること が分かった。ここでPtペーストの場合, Fig. 2 に示 すように 2 本の DTA ピークが検出され， TG 曲線で も2 段階に減量するため, 各々の傾きを算出した。

\section{2 脱バインダー挙動における分散パス回数の影 響}

3 本ロールの分散パス回数を変更させた各種金属 ペーストを作製し，分散回数差による EC 樹脂の燃焼 挙動の変化の有無を次に検討した。

Fig. 4 には, 各種ペーストのパス回数とDTA ピー クの発熱量の関係を示す。強い触媒作用が確認された Pt と Pd は DTA の発熱ピーク面積が著しく大きくな り, 電極と誘電体層が積層された電子部品の焼成を考 えた場合, 脱バインダー時に電極中の樹脂の燃焼が急 激に大きな熱の発生を伴い起きることは, クラックが 非常に発生しやすいと予想される。その対策として は, 燃焼温度以下の低温で長時間かけて脱バインダー を行う等，工夫が必要である。

Fig. 5 には, 各種ペーストのパス回数と DTA ピー ク温度の関係を示す。 $\mathrm{Pd}, \mathrm{Ni}, \mathrm{Cu}$ は EC 樹脂の燃焼

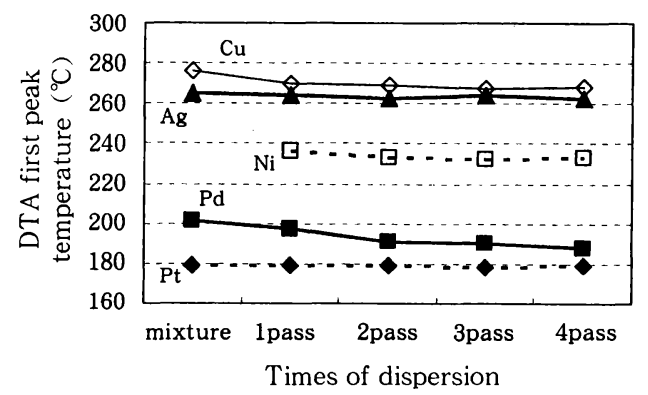

Fig. 5 Relationship between times of dispersion and DTA first peak temperature
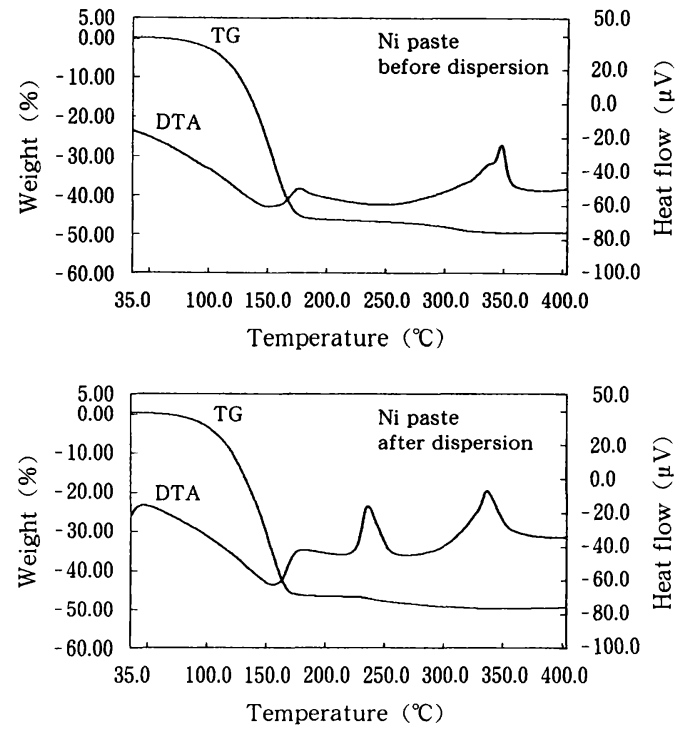

Fig. 6 TG-DTA charts of $\mathrm{Ni}$ pastes of disparsion before and after

に伴うDTA の発熱ピーク温度がパス回数の増加に伴 い低温化した。中でも Fig. 6 に示すように， Ni ペー ストでは分散前では DTA ピークが 1 本であったもの が, 1 パス以降すべてで低温側に新たなピークが発現 し2 本のピークとなった。2 本の DTA ピークの内, より高温の第二ピーク温度の変化はほとんど見られな いが, 第一ピーク温度は分散パス回数の増加に従い低 温化し, その温度とほぼ一致する TG 曲線の変曲点温 度も同様に低下した（Fig. 7）。

また，Pdペーストは検出される DTA ピークは 1 本で, その DTA ピーク温度と同時に TG 変曲点温度 も低温化した。但し，Cuペーストについては，前述 したとおり， $\mathrm{EC}$ 樹脂の燃焼と $\mathrm{Cu}$ 粉の酸化が同時に 起こるため TG 曲線が減少と増加を繰り返すため, $\mathrm{TG}$ 変曲点温度についてはパス回数に伴う大きな変化

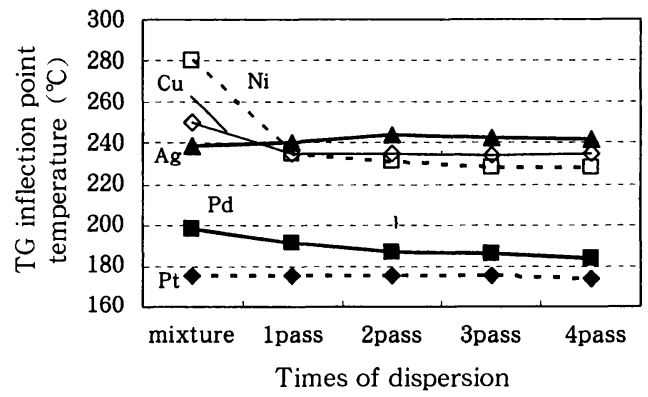

Fig. 7 Relationship between times of dispersion and TG inflection point temperature 

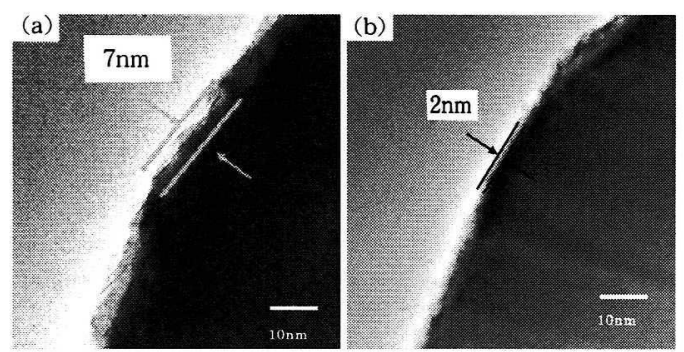

Fig. 8 TEM images of $\mathrm{Ni}$ particle of disparsion before (a) and after (b)

は見られなかった。

$\mathrm{Pd}, \mathrm{Ni}, \mathrm{Cu}$ について，パス回数による $\mathrm{EC}$ 樹脂の 燃焼挙動の変化の原因を検討するために，金属表面に 存在する酸化皮膜に着眼し次に述べる検討を行った。

Fig. 8 (a)（b）には，分散前後で最も変化が確認さ れた $\mathrm{Ni}$ について, 分散前後の $\mathrm{Ni}$ 粒子の表面状態を 確認した TEM 写真を示す。分散前の $\mathrm{Ni}$ 粒子は $7 \mathrm{~nm}$ 程度の均一な $\mathrm{NiO}$ の酸化皮膜で表面が覆われてい る。しかしながら， 4 パス分散後の $\mathrm{Ni}$ 粒子の表面に はその酸化皮膜が $2 \mathrm{~nm}$ 程度と薄くなっていることが 分かった。ここで, 3 本ロールでの分散は, 材料を ロール間に強制的に通過させて行うため, 材料への機 械的損傷が大きいことが分かっている。今回の 4 パス 分散したペーストは, 分散前の金属粉には確認されな いFig. 9 の SEM 写真に示したような粒子が潰れた箔 状粒子も発生しており，3本ロールによる分散方法は 金属粒子への機械的損傷が大きいことが示唆される。 よって, 分散後に酸化皮膜が薄くなる原因としては, 3 本ロールでの分散過程で酸化皮膜が除去されたと考 える。分散過程で一部露出した活性な金属表面は, 触 媒活性がより強いと考えられ, 分散パスの増加に従い 金属表面の露出も増し，EC 樹脂の燃焼が低温化した のではないかと考える。

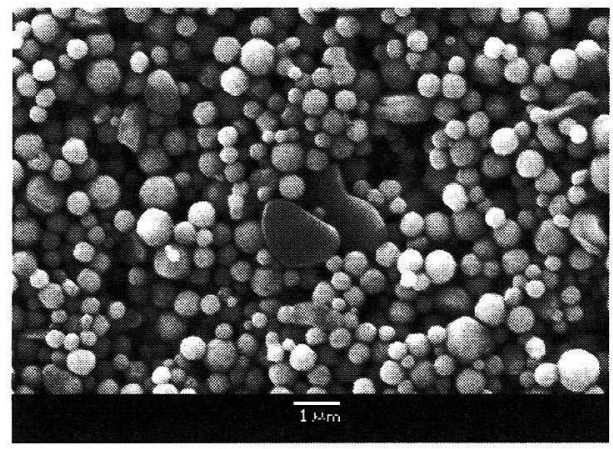

Fig. 9 SEM image of $\mathrm{Ni}$ paste after dispersion
Table 2 Amount of oxygen for various metal powders

\begin{tabular}{cc}
\hline & Oxygen (wt \%) \\
\hline $\mathrm{Pt}$ & 0.06 \\
$\mathrm{Pd}$ & 0.14 \\
$\mathrm{Ag}$ & 0.02 \\
$\mathrm{Ni}$ & 0.48 \\
$\mathrm{Cu}$ & 0.55 \\
\hline
\end{tabular}

そこで，今回使用した各種金属について酸化皮膜の 有無をXRD で調查した。しかしながら，すべてにお いて金属酸化物の結晶相は検出されず，その存在は有 ったとしてもごく微量であることが分かった。

Table 2 には，さらに金属中に含まれる酸素量を不 活性ガス融解一赤外線吸収法で測定した結果を示す。 分散強度によって $\mathrm{EC}$ 樹脂の燃焼挙動に変化が確認さ れた $\mathrm{Pd}, \mathrm{Ni}, \mathrm{Cu}$ については, 酸素量が $\mathrm{Pt}, \mathrm{Ag}$ 上比 較し多く, 表面により多くの酸化皮膜が存在している ことが予想される。そして, 分散時にその酸化皮膜が 除去されることで, $\mathrm{EC}$ 樹脂の燃焼が変化, 促進され ると考えられる。

\section{3 脱バインダー挙動における分散方法の影響}

酸化皮膜の除去の有無による $\mathrm{EC}$ 樹脂の燃焼への影 響をさらに検討するために，材料への機械的損傷が少 ない分散機の一つとして対向衝突分散機で分散した ペーストを作製し，ECの燃焼挙動を検討した。

Fig. 10 には，3本ロールミル品と比較した対向衝 突分散品の TG-DTA 測定結果を示す。対向衝突分散 ペーストは，3本ロールミル分散ペーストと比較し， より低温の DTA 第一ピークも確認されず， TG 変曲 点温度も分散前のペーストと変化が無かった。また,

Fig. 11 に示した TEM による粒子表面の観察において も，3本ロール分散で確認されたような表面の酸化皮

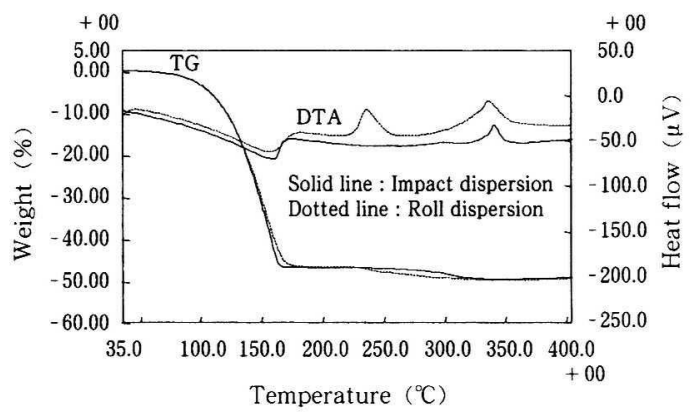

Fig. 10 TG-DTA chart of $\mathrm{Ni}$ pastes made by different process 


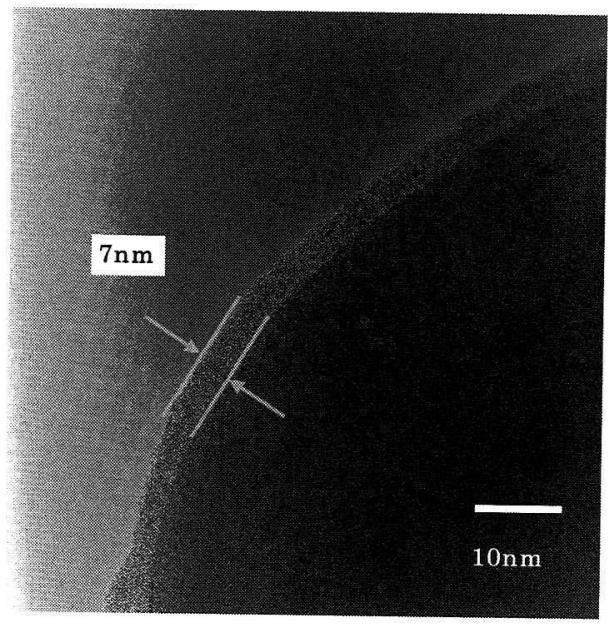

Fig. 11 TEM image of $\mathrm{Ni}$ particle made by impact disparsion

膜の厚みの変化は無かった。

以上の検討より，ペースト分散時における EC 樹脂 の燃焼挙動の変化については, 金属粉の表面状態の 変化にあると考えられ，特に表面に酸化皮膜が存在し ているような金属粉を使用する場合で，分散によりそ の皮膜が破壊される場合に変化が生じると考えられ る。

\section{4. 結言}

各種金属ペースト中の EC 樹脂の燃焼について, 金 属種差, 分散強度上分散方法について検討し，以下の ことが明らかとなった。

1）貴金属ペーストは，その触媒作用によりペースト 中の樹脂の燃焼温度が約 $100 \sim 150^{\circ} \mathrm{C}$ 低下する。特 にPt, Pd で顕著であり，燃焼速度が著しく早くな り, 燃焼時に発生する熱量も大きくなる。電極とセ ラミック層が積層された電子部品の焼成を考えた場 合, 脱バインダー時のクラックが非常に発生しやす いと予想される。その対策としては, 燃焼温度以下 の低温で長時間脱バインダーを行う等, 工夫が必要 である。

2）触媒不活性な酸化皮膜に覆われている金属で，3 本ロールミルの分散ように分散過程でその酸化皮膜 が除去される場合については, 分散の進行とともに 触媒作用が徐々に強くなり, 樹脂の燃焼温度が低温 化する。

3）触媒不活性な酸化皮膜に覆われている金属でも, 対向衝笑分散のように酸化皮膜が除去されない分散 を行った場合, 分散前後で EC 樹脂の燃焼温度に変 化がない。

\section{References}

1) Lee, J. - Y., J. - H. Lee, S. -H. Hong, Y. K. Lee and J. - Y. Choi: "Coating of $\mathrm{BaTiO}_{3}$ Nano-Layer on Spherical Ni Powders for MLCC ${ }^{n}$, Adv. Mater., 15, 1655-1658 (2003)

2) Yamamatsu, J., N. Kawano, T. Arashi, A. Sato, Y. Nakano and T. Nomura: "Reliability of multilayer ceramic capacitors with nickel electrodes", J. Power Sources, 60, 199-203 (1996)

3 ) Shin, Y. I., K. - M. Kang, Y.-G. Jung, J.-G. Yeo, S. - G. Lee and U.Paik: "Investigation of useful or deleterious residual thermal stress component to the capacitance of a multilayer ceramic capacitor", J. Eur. Ceram. Soc., 23, 1427-1434 (2003)

4 ) Ueyama, R., M. Ueyama, K. Koumoto and K. Kuribayashi: "The Effect of $\mathrm{BaTiO}_{3}$ Addition Amounts on the Properties of Ni Paste for Internal Electrodes of
MLC", J. Ceram. Soc. Japan, 109, 351-354 (2001)

5 ) Ueyama, R., M. Ueyama, K. Koumoto, T. Yamamoto and K. Kuribayashi: "The Effect of $\mathrm{BaTiO}_{3}$ Addition Amounts on the Firing and Electric Properties of Ni Paste", J. Japan Soc. Powder and Powder Metall., 48, 392-396 (2001)

6 ) Ueyama, R., K. Koumoto, K. Yubuta and T. Fujii : "The Effect of Particle Size of $\mathrm{BaTiO}_{3}$ Nano-Particles on the Firing Property of $\mathrm{Ni}$ Paste for Internal Electrodes of MLCC ${ }^{n}$, J. Ceram. Soc. Japan, 111, 282284 (2003)

7) Sugimura, K., K. Nakayama and N. Iida: "The Effect of Addition Amounts and Particle Sizes of $\mathrm{BaTiO}_{3}$ on Nickel Electrode Paste”, J. Ceram. Soc. Japan, 115, 182-185 (2007) 